\title{
Spinocerebellar Ataxia Type 12 was not Found in Korean Parkinsonian Patients
}

\author{
Jin Whan Cho, Sung Yeon Kim, Sung Sup Park, Beom S. Jeon
}

\begin{abstract}
Background: Parkinsonism (PD) is occasionally seen in several types of spinocerebellar ataxia (SCA). Mutations in SCA gene have been reported in the patients of parkinsonism without ataxia. Methods: We examined spinocerebellar ataxia type 12 mutation in 877 PD and 199 multiple system atrophy (MSA) patients. Results and Conclusions: No patients showed abnormal SCA12 expansion. It suggests that PD and MSA are not associated with SCA12 and it is not necessary to screen SCA12 in PD and MSA patients.
\end{abstract}

RÉSUMÉ: L'ataxie spinocérébelleuse de type 12 n'est pas présente chez les Coréens atteints de la maladie de Parkinson. Contexte : On observe parfois du parkinsonisme dans plusieurs types d'ataxies spinocérébelleuses (SCA). Des mutations du gène de la SCA ont été rapportées chez des patients présentant du parkinsonisme sans ataxie. Méthodes : Nous avons recherché ces mutations chez 877 patients parkinsoniens et chez 199 patients atteints d'atrophie multisystémique. Résultats et conclusions : Aucun patient n'était porteur d'une expansion anormale du gène de la SCA de type 12. Ceci porte à croire que la maladie de Parkinson et l'atrophie multisystémique ne sont pas associées au gène de la SCA 12 et qu'il n'est pas nécessaire d'en faire le dépistage chez les patients atteints de la maladie de Parkinson et de l'atrophie multisystémique.

Can. J. Neurol. Sci. 2008; 35: 488-490

Spinocerebellar ataxias (SCA) are a heterogeneous group of autosomal dominant neurodegenerative disease characterized by progressive cerebellar ataxia, but can be associated with various combination of neurological symptoms. It is well known that parkinsonism (PD) is occasionally associated with ataxia in several types of SCA. ${ }^{1}$ Furthermore, mutations in SCA gene have been reported in the patients of parkinsonism without ataxia..$^{2-13}$

Holmes and his colleagues first reported expansion of unstable CAG repeat in the 5' region of the PPP2R2B gene in a single large pedigree of German descent as a SCA type $12 .{ }^{14}$ Subsequently, there have been several reports in large Indian pedigrees. ${ }^{15,16}$ Reported SCA12 patients showed a similar phenotype which begins with action tremor and is followed by variable neurological signs and symptoms, including cerebellar ataxia, hyperreflexia, dementia, and parkinsonism. ${ }^{17}$

We have shown previously that SCA2 is not rare in Korean parkinsonian patients. ${ }^{13}$ This observation prompted us to investigate SCA12 in our patients. As a part of screening of gene mutation in Korean parkinsonian patients, CAG expansions in the 5' region of the PPP2R2B gene in $877 \mathrm{PD}$ and 199 multiple system atrophy (MSA) patients was performed.

\section{Patients And Methods}

All of the patients were native Koreans. All patients were personally observed and have been followed up regularly by the senior neurologist at Seoul National University Hospital since
1993. Blood samples were collected after obtaining written informed consent from each participant. The genetic study was approved by the IRB of Seoul National University Hospital. Parkinson's Disease was diagnosed using the United Kingdom Parkinson's Disease Society Brain Bank criteria, with the exception of a positive family history. ${ }^{18}$ All MSA subjects were diagnosed with probable MSA according to the Consensus Criteria. ${ }^{19}$

The DNA from 100 healthy subjects was received from the gene database at the Department of Laboratory Medicine, Seoul National University Hospital. They were all healthy individuals who visited our hospital for annual routine health check-ups. The mean age of the patients was $49.3 \pm 9.3$, and the ratio of males to females was 47:53.

A total of 1076 parkinsonian patients $(\mathrm{PD}=877, \mathrm{MSA}=199)$ were included in the study. In the PD patients, the mean age at

From the Departments of Neurology (JWC, BSJ), Laboratory Medicine (SSP, SYK), BK21 NRI and CRI, College of Medicine, Seoul National University (JWC, SYK, SSP, BSJ), Metropolitan Boramae Hospital (JWC), Seoul National University Hospital (SYK, SSP), Seoul, South Korea.

Received October 12, 2007. Final Revisions Submitted March 26, 2008. Correspondence to: Professor Beom S. Jeon, Department of Neurology, Seoul National University College of Medicine, 28 Yeongeon-Dong, Jongno-Gu, Seoul 110-744, South Korea. 
onset was $55.7 \pm 11.2$ (age range $=12-81$ ). The onset age was under 50 years in 265 of the patients with PD. The PD patients were 389 men (mean age at onset $=55.2 \pm 12.2$ ) and 488 women (mean age at onset $=56.0 \pm 10.4$ ). In the MSA patients, the mean age at onset was $60.6 \pm 8.1$ (age range $=36-83$ ). Ninety-four of the MSA patients were men (mean onset age $=62.1 \pm 8.0$ ) and 105 were women (mean age at onset $=59.4 \pm 8.0$ ). Twenty-seven of the 877 PD and one of the 199 MSA patients had at least one firstdegree relative (parent or sibling) with parkinsonism. The MSA patient with a positive family history came in age 59 with progressive gait disturbance and urinary urgency and incontinence, which had begun ten months prior. On examination, he had a slightly masked face, mild dysarthria, mild impairment of limb dexterity and rigidity, which was worse on the left side, and an unsteady but narrow-based gait. He was given Sinemet巴 250/25 1.5 tablets tid but his condition did not improve. He continued to deteriorate, mostly in gait and balance, and died at age 63. Of his five siblings, his eldest brother, who is currently 70 years old, has had L-dopa responsive-parkinsonism since age 54. He is on Madopar ${ }^{\circledR}$ 200/50 1.5 tablet qid, selegiline $5 \mathrm{mg}$ bid, amitriptyline $10 \mathrm{mg}$ qd with motor fluctuation and dyskinesia.

Total DNA was extracted from white blood cells using a DNA isolation kit (Gentra PureGene, Gentra System, Inc., Minneapolis, MN) according to the manufacturer's protocol. Polymerase chain reaction (PCR) amplifications of the trinucleotide repeats in the PPP2R2B gene were performed with the forward primer 5'-Hex-ACTGCTGCTGGGAAAGAGTC3', and reverse primer 5'- ACTCACCCTCACACCCACAC-3' designed by Primer3 (http://frodo.wi.mit.edu/cgi-bin/primer3/ primer3_www.cgi). All PCR procedures were performed in a 10 $\mathrm{uL}$ total reaction volume using TaKaRa LA Taq ${ }^{\mathrm{TM}}$ with a GC Buffer system (Takara Bio Inc., Japan), containing 1X GC buffer, $0.4 \mathrm{mM}$ dNTPs, 2 pmoles of each primer, $50 \mathrm{ng}$ of DNA, and $0.5 \mathrm{U}$ of LA Taq polymerase. All cycling profiles incorporated an initial denaturation step at $94^{\circ} \mathrm{C}$ for 5 minutes, 35 amplification cycles $\left(30\right.$ seconds at $94^{\circ} \mathrm{C}, 1$ minute at $58^{\circ} \mathrm{C}$ and 1.5 minutes at $72^{\circ} \mathrm{C}$ ), and a final cycle of 5 minutes at $72^{\circ} \mathrm{C}$ and 45 minutes at $60^{\circ} \mathrm{C}$. The fluorescent PCR products were run on an ABI3100 Genetic Analyzer (Applied Biosystems, Foster City, CA) and the data were analyzed using the GeneMapper version 3.7 software. Each repeat number was confirmed by sequencing in several samples.

\section{RESULTS}

The range of CAG repeat size of SCA12 alleles was 4 to 19 in normal controls. The most frequent allele size was 10 repeat. There was no difference in allelic distribution between patients and control group. The range of CAG expansion was 4 to 26 and 4 to 21 in PD and MSA patients, respectively. Distribution of SCA12 alleles is shown in the Figure.

\section{DisCUSSION}

Even though cerebellar ataxia is the hallmark in SCAs, parkinsonism has been occasionally seen. There are several reports of a mutation in various SCA genes as a cause of typical PD phenotype with good response to L-dopa. ${ }^{2-13}$ The incidence of SCA mutation was more frequent in familial PD than sporadic $\mathrm{PD}^{5-7}$ but there are several reports of sporadic PD with SCA mutations. ${ }^{9,11,13}$

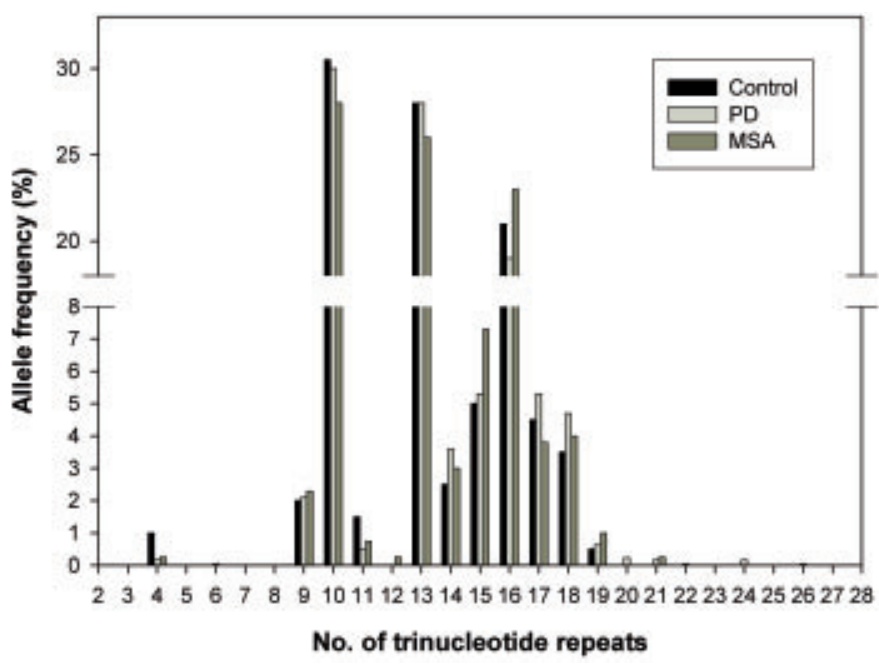

Figure: Distribution of SCA12 alleles in the patients and healthy individuals.

Most previous studies of SCA mutation in PD were performed in SCA type 2,3,8 and 17..$^{2-13,20}$ It appeared reasonable to see the SCA12 mutation in PD because SCA12 has been described to have parkinsonism in the disease course. ${ }^{17}$ As far as we know, this is the first large cohort of PD and MSA for mutations in SCA12. In our results, a few patients showed larger CAG triplets (20 to 26 repeats) than those of our normal control (4 to 19 repeats). However, 28 triplets was accepted to be normal in other studies. ${ }^{17}$ Therefore, no patients with PD and MSA in our population showed abnormally extended CAG repeat.

It suggests that testing for SCA12 mutation may not be necessary in the patients with parkinsonism.

\section{ACKNOWLEDGEMENTS}

This study was in part supported by a grant of the Korea Health 21 R\&D Project. Ministry of Health \& Welfare, Republic of Korea (03-PJ10-PG13-GD01-0002). We thank Mr. Chung Suk-Gyoo and Shinyang Cultural Foundation for their generous donation.

\section{REFERENCES}

1. Manto MU. The wide spectrum of spinocerebellar ataxias (SCAs). Cerebellum. 2005;4:2-6.

2. Gwinn-Hardy K, Chen JY, Liu HC, Liu TY, Boss M, Seltzer W, et al. Spinocerebellar ataxia type 2 with parkinsonism in ethnic Chinese. Neurology. 2000;55:800-5.

3. Gwinn-Hardy K, Singleton A, O'Suilleabhain P, Boss M, Nicholl D, Adam A, et al. Spinocerebellar ataxia type 3 phenotypically resembling parkinson disease in a black family. Arch Neurol. 2001;58:296-9.

4. Furtado S, Farrer M, Tsuboi Y, Klimek ML, de la Fuente-Fernández $\mathrm{R}$, Hussey $\mathrm{J}$, et al. SCA-2 presenting as parkinsonism in an Alberta family: clinical, genetic, and PET findings. Neurology. 2002;59:1625-7. 
5. Payami H, Nutt J, Gancher S, Bird T, McNeal MG, Seltzer WK, et al. SCA2 may present as levodopa-responsive parkinsonism. Mov Disord. 2003; 18:425-9.

6. Lu CS, Wu Chou YH, Kuo PC, Chang HC, Weng YH. The parkinsonian phenotype of spinocerebellar ataxia type 2. Arch Neurol. 2004;61:35-8

7. Shan DE, Liu RS, Sun CM, Lee SJ, Liao KK, Soong BW. Presence of spinocerebellar ataxia type 2 gene mutation in a patient with apparently sporadic Parkinson's disease: clinical implications. Mov Disord. 2004;19:1357-60.

8. Wilkins A, Brown JM, Barker RA. SCA2 presenting as levodoparesponsive parkinsonism in a young patient from the United Kingdom: a case report. Mov Disord. 2004;19:593-5.

9. Wu YR, Lin HY, Chen CM, Gwinn-Hardy K, Ro LS, Wang YC, et al. Genetic testing in spinocerebellar ataxia in Taiwan: expansions of trinucleotide repeats in SCA8 and SCA17 are associated with typical Parkinson's disease. Clin Genet. 2004: 65: 209-214.

10. Simon-Sanchez J, Hanson M, Singleton A, Hernandez D, McInerney A, Nussbaum R, et al. Analysis of SCA-2 and SCA3 repeats in Parkinsonism: evidence of SCA-2 expansion in a family with autosomal dominant Parkinson's disease. Neurosci Lett. 2005;382:191-4.

11. Lim SW, Zhao Y, Chua E, Law HY, Yuen Y, Pavanni R, et al. Genetic analysis of SCA2, 3 and 17 in idiopathic Parkinson's disease. Neurosci Lett. 2006;403:11-14.

12. Modoni A, Contarino MF, Bentivoglio AR, Tabolacci E, Santoro M, Calcagni ML, et al. Prevalence of spinocerebellar ataxia type 2 mutation among Italian Parkinsonian patients. Mov Disord. 2007;22:324-7.
13. Kim JM, Hong S, Kim GP, Choi YJ, Kim YK, Park SS, et al. Importance of low-range CAG expansion and CAA interruption in SCA2 Parkinsonism. Arch Neurol. 2007;64:1510-8.

14. Holmes SE, O'Hearn EE, McInnis MG, Gorelick-Feldman DA, Kleiderlein JJ, Callahan C, et al. Expansion of a novel CAG trinucleotide repeat in the $5^{\prime}$ region of PPP2R2B is associated with SCA12. Nat Genet. 1999;23:391-2.

15. Bahl S, Virdi K, Mittal U, Sachdeva MP, Kalla AK, Holmes SE, et al. Evidence of a common founder for SCA12 in the Indian population. Ann Hum Genet. 2005;69:528-34.

16. Fujigasaki H, Verma IC, Camuzat A, Margolis RL, Zander C, Lebre AS, et al. SCA12 is a rare locus for autosomal dominant cerebellar ataxia: a study of an Indian family. Ann Neurol. 2001;49:117-21.

17. Holmes SE, O'Hearn E, Margolis RL. Why is SCA12 different from other SCAs? Cytogenet Genome Res. 2003;100:189-97.

18. Hughes AJ, Daniel SE, Kilford L, Lees AJ. Accuracy of clinical diagnosis of idiopathic Parkinson's disease: a clinicopathological study of 100 cases. J Neurol Neurosurg Psychiatry. 1992;55:181-4.

19. Gilman S, Low PA, Quinn N, Albanese A, Ben-Shlomo Y, Fowler $\mathrm{CJ}$, et al. Consensus statement on the diagnosis of multiple system atrophy. J Neurol Sci. 1999;163:94-8.

20. Wu YR, Fung HC, Lee-Chen GJ, Gwinn-Hardy K, Ro LS, Chen ST, et al. Analysis of polyglutamine-coding repeats in the TATAbinding protein in different neurodegenerative diseases. J Neural Transm. 2005;112:539-46. 